\title{
Degn Kjærbøllings optegnelser fra treårskrigen
}

\author{
Ved Tage Brummer, Asserballe.
}

Den 24. januar 1832 blev Lauritz Georg Kjærb $\phi l l i n g$ kaldet til lærer i Asserballeskov skole på Als; her blev han til 13. februar 1836. Grunden til, at han flyttede så hastigt, er både ligetil og gyldig nok: Han blev den 26. februar samme år i Asserballe kirke viet til Anne Marie Becker (* 17. april 1816 som datter af degn og skolelærer Ernst Becker og hustru Cathrine Hansdatter i Asserballe by). Og med degnens datter fulgte embedet, idet Kjærbøllings svigerfar var d $\varnothing d$ den 20 . oktober 1835, kun 553/4 år gammel som degn og skolelarer i Asserhalle by.

Lauritz Georg Kjærbølling var søn af skolelærer i Dyndved skole, Egen sogn: Jørgen Kjærbølling og hustru Marie Lorentzen. Her f $\varnothing$ dtes han den 24. november 1810. Som sin far og svigerfar blev Kjærbølling en meget dygtig lærer, hvis virke og minde endnu kan spores tydeligt her i Asserballe sogn. Med forbavsende sikkerhed og historisk nøjagtighed har Herman Bang tegnet hans billede $\mathrm{i}$ bogen om Kjærbøllings yngste datter »Tine«, hvor vi finder ham som den »gamle Bølling «. Kjærbølling havde i sit agteskab kun de to d $\varnothing$ tre Marie Cathrine $(* 11$. oktober 1838; gift den 16. oktober 1857 i Asserballe kirke med skovfoged i Asserballeskov Stephan J $\phi r g e n s e n$ Schmidt) og Cathrine Marie ( $\gg$ Tine $* 30$. januar 1847 ; gift den 18 . november 1870 i Ketting kirke med forpagter - senere gorsejer i Skåne Christian Petersen fra Bro i Ketting sogn).

I Danevirke-romanen »Tine tegner Herman Bang et fint, stilfærdigt billede af den gamle Skolelærer Kjærbølling som en ældet, bekymret og mærket mand, der ikke har mange kræfter og år tilbage, og lader dette være resultatet af det 
sviende nederlag i krigen 1864. På dette punkt arbejder Herman Bang dog digterisk frit; for degn Kjærbølling blev i 1863 ramt af en hjerneblødning, der delvis kostede ham førligheden og arbejdsevnen, så at han i 1865 søgte $\circ g$ fik sin afsked. Så levede han da sammen med sin kone "på aftægt « hos datteren og svigers $\varnothing$ nnen på skovfogedstedet i Asserballeskov. Det meste af tiden lå han - delvis lammet - til sengs, men hans sanser og åndsevner fejlede intet. Her levede han så under god pleje de sidste 23 år af sit liv, indtil han døde den 30. marts 1888 og blev begravet Langfredag, 5 dage senere. Hans enke overlevede ham kun 2 år, hun d $\phi$ de den 2 . juli 1890.

Mærkeligt nok fik datteren »Tine« samme skæbne som sin far: ramt af en hjerneblødning levede hun, lammet $i$ højje side, i det samme åremål, 23 lange år, inden hun døde den 5. december 1921 i Hälsingborg.

Men lad én af dem, der har kendt denne prægtige og omhyggelige lærer, dette kærnedanske og karakterfulde menneske, give os det rigtige billede og den rette vurdering. Daværende pastor Nissen i Asserballe sagde i sin meget lange ligprædiken ${ }^{1)}$ over Kjærbølling bl. a.:

》Omringet af mange bevægede Hjerters Deeltagelse hviler i denne Forsamlings Midte en gammel Hædersmand, udløst fra Livets Strid og Møie. — - — Et godt Navn bliver evindeligt « siger Sirach; og dette gode Navn er Kjærbølling: iblandt - - - hans Foresatte, der altid have anerkendt og paaskjønnet hans Virksomhed; iblandt hans Embedsbrødre har hans Navn endnu ogsaa iblandt den yngre Slægt saa god en Klang og fornemmelig i denne Menighed, i hvis Midte han har virket og lidt $i$ langt over et halvt hundrede Aar. Hans frugtbare Virksomheds Dage gjemmes i levende Minde i mange taknemlige Hjerter her og andetsteds, men også hans lange Lidelsers tunge Aar have skjænket denne Menighed Udbytte, et Exempel paa Taalmodighed og Frimodighed under Korset. Han, som allerede en

1) Bevaret $i$ afskrift foretaget af Tines ældste s $\varnothing n$, Fritz Petersen, Rødovre, efter en ældre afskrift af ligprædikenen, som mosteren har foretaget. 
Menneskealder igjennem havde været Lærer, var selv påny efter Herrens vise Raad blevet Discipel. - - -

Men ærværdig var han midt $i$ sin Svaghed. Og var der end Tider, da Lettelse kunde spores, da han kunde forlade Sygelejet, ja endog engang kunde komme her til Byen og i Guds Hus, saa var der dog stadig Svaghed og Lidelse nok - - men han bar selv de tungeste Prøvelser, Smerter og Sorger med en Taalmodighed og Sindsstyrke, der ei blot strakte til for hans egen Deel. - - Med levende Interesse omfattede han Alt og Alle, der stod i Forbindelse med hans tidligere Virksomhed. Det var ikke som om man kom til en Syg og Lidende, der trængte til Trøst og Opmuntring, men snarere som stod man overfor en Mand, der endnu havde den Opgave at være Andre til Vejledning og St $\varnothing$ tte. Saa blev han da i Korsets Skole et Mønster til Efterf $\varnothing$ lgelse -- - - ligesom han forhen i sine Velmagts Dage var et M $\phi$ nster til Efterligning i Henseende til Benyttelsen af de af Herren betroede Pund.

Allerede på Seminariet var han et Lys iblandt dem, der sammen med ham forberedte sig til en Larers vigtige Gjerning. Med udmærkede evner forbandt han en strabsom Flid efter at tilegne sig alt, hvad der kunde komme hans Gjerning til Nytte. $\mathrm{Og}$ ligesom hans mere bekjendte Broder ${ }^{2}$ ) naaede han da ogsaa at yde Fortrinligt $i$ sit Fag. Som ganske ung Lærer bragte han frisk Liv og en ny Aand ind $i$ »Skovens « Skole, og da han snart blev sin senere Svigerfaders, Degn Beckers Efterfølger i Embedet her i Byen, da udfoldede han en Virksomhed, der endnu er uforglemt og hvoraf smukke Frugter ere at spore end den Dag i Dag. Mange blandt de Tilstedeværende ville mindes med hvilken Værdighed han her i Guds Hus udfyldte sin Plads som Præstens Medhjælper og Menighedens Forsanger. Og ligesaa klart lever Mindet om ham fra Skolen, hvor han ret var i sit Element; hvor han forstod at vinde de unge Hjerter samtidig med at han vakte dem $i$ Tænksomhed og Lærelyst og veiledede dem til Anstand og Orden i alle Forhold. Ogsaa udenfor Kirke

2) Ornitologen og grundlaggeren af Zoolngisk Have, Ernst Kjærbølling. 
og Skole var han s $\phi$ gst som kyndig Raadgiver, en anset og betroet Mand i Livets mangehaande Anliggender, og de Præster, som her i Sognet traadte i Forhold til ham, havde Anledning til at agte og elske ham for den Maade, hvorpaa han kom dem imøde og støttede deres Virksomhed i Menigheden.

En lang Række af Aar fik han Naade til at virke med Velsignelse $i$ denne Stilling, en Menneskealder igjennem var han til Velsignelse og St $\varnothing$ tte for saare mange, og stor var Sorgen og Savnet, da han bøiet af Sygdommens Byrde maatte trække sig tilbage fra den Gjerning, der havde baaret saa rige Frugter, under almindelig Paaskjønnelse og Anerkjendelse, udmærket af sin Konge, anset og afholdt af Alle, der kjendte han - - -

Endnu faa Dage $f \phi r$ hans D $\phi d$ formaaede hans Aand dog endnu at løfte sig op over Legemets svære $N \phi d$ og Elendighed - - livlig og inderlig bevæget bekjendte han sin egen Svaghed og Uværdighed overfor den trofaste Guds store Naadegaver - - og med kraftig Røst og forklaret Blik sang han endnu engang - - - den smukke Paaskesalme: $\gg$ glade Budskab for mit Hjerte, Forløseren opstanden er «! fra først til sidst og med mange kjærlige Ord tog han Afsked med mig for dette Liv; en gribende Afskedsstund, som stedse vil forblive mig uforglemmelig! $\ll-\ldots$

På Asserballe kirkegård er der en fredet degnebegravelse. Her står to små prunkløse marmorplader:

Her hviler

Dhm. fhv. Degn og Larer i Atzerballig

Lauritz Georg Kjærbølling

* 24. November 1810

+30 . Marts 1888
Her hviler Anne Marie Kjærbølling

f. Becker

* 17. April 1816

+ 2. Juli 1890

Haabet opfyldtes 


\section{$\gg$ Historiske Bemærkninger fra Krigsaarene 1848-51 samt de nærmest foregaaende $\left.\ll^{3}\right)$}

Dengang Stænderinstitutionen i 1834 kaldtes ilive, bekymrede man sig her paa Øen meget lidt om det offentlige Liv; den slesvigske Presse havde ikke endnu udøvet nogen gavnlig Virksomhed i denne Retning. Stænderinstitutionen modtoges derfor ogsaa her i Sognet med Kulde og Ligegyldighed, og man hørte ikke sjælden Folk sige: »Det kommer an paa, om det ogsaa kan betale sig at have en saadan Indretning. \& Hertil kom den Omstændighed, at den stænderske Valglov kun tillod meget Faa at afgive Stemme ved Valgene, hvorimod det store Flertal, omtrent $\% / 6$ af Sognets bosatte Mænd, vare udelukkede som Valgbare og Valgberettigede. Dog troede de Samme, der havde Valgret, at varetage deres Interesser bedst ved at vælge til Deputeret en Mand, der ikke stod i Afhængighedsforhold til Hertugen af Augustenhorg, Godsherren, og ikke var en personlig Ven af denne Fyrste.

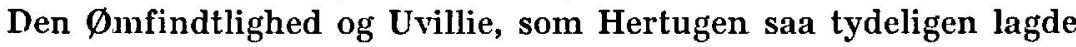
for Dagen ved Udfaldet af det f $\varnothing$ rste Valg (Provst Ebbesen i Svenstrup blev valgt til Deputeret og C. Bonefeld i Ulkebølle til Suppleant), forøgede ikke lidet Interessen for Institutionen, og denne steeg naturligvis, da Hertugen senere, tildeels af politiske Grunde, blandede sig saameget i Valgsagen. Men hvormeget der end directe $\mathrm{og}$ indirecte blev gjort fra denne Side for at indvirke paa Vælgerne, - her i Sognet valgte de dog, med Undtagelse af nogle Faa, stedse paa gode danske Mænd, og de Faa, der tildels ved Trusler, tildels ved Løfter lode sig forf $\phi$ re til at fornægte deres bedre Overbevisning, have bitterligen angret dette Skridt, og senere sluttet sig til Sognets $\emptyset$ vrige Vælgere.

Under Krigen, Aar 1848, da et Folkeraad for Øen oprettedes, valgtes der efter samme indskrænkede Valglov; men da der i Slutningen af 1849 oprettedes en Repræsentantforsamling for hele Øen, der skulde styrke Folkeraadet og oplive Almenaanden, og hvortil enhver Mand i Sognet, der havde egen Disk og Dug,

3) Fra Asserballe prasteembedes Copibog 1851.

Kjærbølling anvender som ventelig gotisk skrift, men i egen- og stednavne latinske bogstaver. Disse er her angivet ved kursiv. 
liunde vælge, mødte fra Adzerballig Sogn 115 Vælgere og afgave deres Stemme.

Det loyale danske Sind, som ved de omtalte Valg havde gjort sig gældende, fandt til forskjellige Tider, og især under Krigen, Næring og Styrke i de mange Petitioner og Adresser, affattede i ægte dansk Aand, der, forsynede med talrige Underskrifter, bleve indsendt til høje Vedkommende. Meget ofte bleve Sognemændene anmodede af Sognets Skolelærere om at give Møde i saadanne Anliggender, og Anmodningen blev altid med Glæde efterkommet. - Det samme Sind gjorde sig gjældende, når den augustenborgske Sangforenings Medlemmer droge omkring i Egnen for at præsentere deres tyske Fane og afsynge tyske og slesvigholstenske Sange. Kun Faa indfandt sig ved saadanne Lejligheder, og de Samme for det Meste kun for at tilkjendegive deres Uvillie mod, og Afsky for saadanne Optog.

Ved en (maaske i 1846) afholdt Jagt her i Sognet, blev Hertugen opmærksom paa en Bondekarl, hvis Pibehoved var prydet med en Tegning af det danske Flag, og idet han forlangte at faa Piben, spurgte han med Uvillie, hvor dette Pibehoved var bleven kjøbt.

Saameget varslede om, at man havde Ondt isinde, og man hørte ofte Een og Anden sige: »Det bliver vist galt, hvis Kongen ikke passer paa itide«. - Og det gik saaledes; det Onde kom i Form af et organiseret Oprør. Da Fæstningen Rendsborg var tagen af Oprørerne d. 23. Marts 1848, vidste man det her 2 Dage senere, og Efterretningen herom virkede som et electrisk Slag. Budskabet kom fra Præstegaarden: den unge Pastor Schlaikier ${ }^{4}$ ), en særdeles begavet og venlig Mand, der i den korte Tid (1 Fjerdingaar) han havde været Menighedens Præst, havde vundet megen Agtelse og Yndest, men sværmede for Tysklands Storhed, og for Slesvigs Indlemmelse i Tyskland, havde paa en

4) Hans Peter Schlaikier, født i Egernsund, hvor faderen var teglværksejer, d. 30/VI 1822. Stud. Kiel 23/IV 1842. Cand. Gott. 1847. Sognepræst i Asserballe 1847. Diakon i Haderslev 1849-50 entledigt herfra. Seminarielærer i Segeberg 1851. Seminariedirekt $\varnothing \mathbf{r}$ i Heldburgshausen 1852. Regerings- og over-skoleråd i Meiningen 1884-91. Hans søster var gift med provst Prahl i Øsby - efter 1864 i Gammel Haderslev. 
Reise til Tonningen været i Rendsborg, og med egne $\emptyset$ jne seet Oprorernes Triumpf. Han kom hjem beruset af Glæde, og ubekjendt med den Folelse for Konge og Fadreland, der boede i hans Sogneb $\phi r^{\prime}$ s Bryst; med synlig Glade fortalte han at Rendsborg var falden, at den danske Konge var i Fangenskab, at de danske ikke kunde gjøre nogen Modstand o. s. v., og der øieblikkelig organiseredes en frivillig Landstorn af Unge og Gamle (selv 60 aarige Mand gik ined) troede Præsten, at burde fra Prædikestolen paa en Fasteonsdag tale derimod, og opfordrede til at »stikke Svardet i Skeden«. Med Et var al 'Tillid til Prasten borte, men man lod ham i Fred; han blev d. 7 'de April suspenderet, og den 15'de April bortfyrt, for ikke mere at vende till)age som Menighedens Prast.

Under den 3 aarige Krig i Aarenc 1848, 1849 og 1850, viste ogsaa denne Menighed, som de andre Menigheder paa $\emptyset \mathrm{en}$, en urokket Troskab mod Konge og Fædreland, og en ligesaa stor Forbitrelse mod Oprørerne. Hvad der af de forskjellige Autoriteter forlangtes for at sikkre Øen mod Overfald, eller $i$ andre militaire Øiemed, præsteredes uden Knur, og skjøndt Atzerballig Sogn er lidet i Størrelse (det tæller ikke 800 Sjæle) og lidet velhavende, var det altid blandt de forste til at yde frivillige Bidrag til Krigens Forelse, til Saarede og Qvæstede og Faldnes Efterladte og til de Sognebørn, der gjorde Feldttogene med, og de Summer, der således offredes paa Fædrelandets Alter, udgjorde vel over 300 Rdlr.

Spændingen under Krigen var stor; fra Skolerne meddeltes Sognebeboerne, hvad Bladene og den nære Telegrapf ved Almsted $^{5}$ ) berettede om Krigens Gang. Da Efterretningen om den ulykkelige Tildragelse i Eckernf $\phi$ rdefjord Skjærtorsdag 1849 nauede hertil, bleve alle nedslagne, og Mange kunne ikke holde Taarerne tilbage; da Fredericia-slaget og Idsted-slaget varc vundne var der almindelig Jubel. Saavel i 1848 som 1849 laac

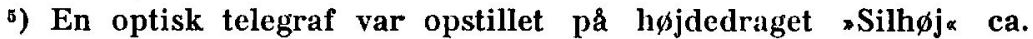
$1 \mathrm{~km}$ fra Asserballe præstegård, cf. Herman Bangs forord til førsteudgaven af Tine, hvor moderen netop tager afsked her med byen, markerne, skovene og fjordene. *Mor, hvorfor græder du?* »Fordi

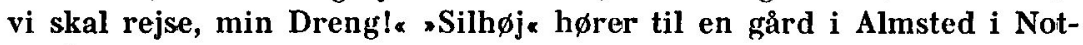
mark sogn. 


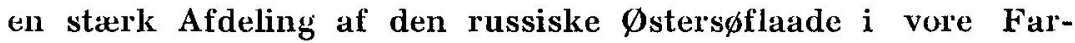
vande, og i længere Tid havde den Station imellem Als og Er $\phi e$. Flere Sogneboere vare da ombord paa russiske Skibe, og bleve særdeles vel modtagne. - Efter Slaget ved Slesvig Paaskedag 1848 og Armeens Retraite til Als, kom 11. Bataillon, der bestod af Jyder her til Sognet. Der udspandt sig snart et meget venligt Forhold mellem disse gjæve, trofaste og godmodige Folk og Sognets Beboere. Efter 5'te Juni-slaget og indtil midt hen i Maaneden blev en Afdeling af Herregaardsskytterne indqvarteret her; flere Adelige, deriblandt Grever og Baroner, vare med i dette Chor. I Slutningen af Decbr. havde vi 1'ste Bataillon (Kulsviere). Fra Begyndelsen af 1849 til Slutningen af Marts 3'die Forstæerknings-Bataillon, i de f $\phi$ rste Dage af April 2 Compagnier af 2'den Reserve-Bataillon. - Længere hen i Maaneden laae Fodgarden her $i$ nogen Tid, i Slutningen af Aaret og i den f $\phi$ rste Halvdeel af 1850 endeel Mandskab af Reservetraindepotet og til samme Tid 3'die Reserve Jægerchor, til forskjellige Tider havde vi ogsaa Dragoner af 4'de Regiment og Artillerister af 3 Batterier.

Forholdet mellem Militairet og Værterne var i det Hele venligt og godt, og der h $\phi$ rtes sjælden Klage paa nogen af Siderne. Alt blev punktligt og ret godt betalt, og det kan næppe med Grund paastaaes, at der var Tab forbunden med Indqvarteringen; især Smaafolk havde $\mathrm{i}$ den Tid lettere ved at faae rede Penge.

For Huusmødrene var det imidlertid en meget streng Tid og B $\phi$ rneopdragelsen blev fors $\phi \mathrm{mt}$; det manglede paa Tid og Ro hertil. - Ogsaa Skoleundervisningen leed tidt Afbræk, dog samlede ogsaa Børnene, ved at see saameget Nyt, og leve i et saa bevæget Liv, endeel gavnlig Erfaring. Sædeligheden led tilsyneladende ikke meget ved den lange Indqvartering; vi havde $i$ Krigsaarene kun 2 uægte F $\phi$ dsler at beklage. -

Af Atzerballig Sogn deeltoge 17 i Krigen tillands og 18 Sølimiter ${ }^{\mathrm{b}}$ ) fra Atzerballigskov (som udgjorde et Sølimitdistrict) tilvands. -

6) Ordet sølimit bruges dels om et distrikt ved havet, $i$ hvilket der udskrives værnepligtige til flåden, dels om de personer, der var indskrevet $i$ s $\phi$ rullen og derved forpligtet til at gøre tjeneste $i$ marinen 
Saavel af de Første som af de Sidste vare ikke Faa Familiefædre; de Familier, som ved Fors $\phi$ rgernes Fjernelse vare blevne br $\varnothing$ dl $\varnothing$ se, bleve godt underst $\varnothing$ ttede fra Sognets Side. - Paa 2 nær, hvoraf den Ene døde paa Augustenborg Lazareth af Typhus, den Anden ved en Kanons Sprængning fandt sin Død i Nyborg, vendte Alle tilbage til Hjemmet. Kun 2 Soldater bleve saarede, den Ene let, den Anden mistede ved en Straifkugle Synet paa det ene Øie, og erholder som Invalid en aarlig Understøttelse. - Efter Krigens Ophør vendte tilbage til Sognet 2 fremmede Soldater, som nu begge ere gifte og bosatte ${ }^{i}$. Bortrejst fra Sognet er een Pige, som har ægtet en Soldat, der har hjemme i Fyen. -

Een Soldat af 2'det Reserve-Jægerchor, som for en begaaet Forseelse fik Arrest i en Lade, skjød sig selv og ligger begraven paa Kirkegaarden. Ogsaa hændte den Ulykke, at en lille Dreng, der endnu var aldeles ubekjendt med Virkningen af et Skud, fik fat paa en ladt Pistol, og skød en anden lille Dreng, sin Legekammerat, en Kugle gjennem Hovedet, der strax endte hans $\left.\mathrm{Liv}^{8}\right)$.

Krigen er lykkelig endt, og Mand og Qvinde kunne atter i Fred og Ro passe deres Gjerning. Gid vi Alle, idet vi paaskjønner dette Gode, maa vedblive at styrke og pleje i os det Borgersind, der gjærne bringer Fædrelandet ethvert Offer i Fred og i Krig!

Med dette varmhjertede $\emptyset$ nske slutter degn Kjærbølling sin beretning. Hvorfor degn Kjærbølling har skrevet så lang en beretning her, og hvordan han har fået copibogen i hænde, kan man idag ikke udtale sig om med sikkerhed. Det skal dog her an-

7) Ungkarl: Christen Jensen, f. 7/XII 1824 i Hvirring Sogn, Randers Amt, copuleret 2/V 1851 med Pigen Anna Charlotte Lassen, f. 17/IX 1818.

Ungkarl: Peter Mikkelsen, f. 21/VI 1817 i Yding Sogn, Aarhus Amt, copuleret 9/VII 1851 med Pigen Karen Schmidt, f. 26/II 1821.

8) Jørgen Hansen, død 9/VI 1848, 83/4 Aar gammel, Søn af Inderste Niels Hansen, Atzerballigskov. Dræbt ved et Vaadeskud med en Pistol, medens det beredne Jægercorps fra Øerne var indqvarteret her i Byen. 
føres, at degn Kjærbølling på samme tid i samtlige kirkeb $\emptyset$ ger har foretaget flere indf $\varnothing$ relser både af d $\phi b t e$, copulerede og d $\varnothing \mathrm{de}$ og især $\mathrm{i}$ og omkring de urolige år 1848-50, hvor bestandig nye præster konstitueredes og afsattes efter det skiftende udfald af krigen, og hvor præstegaarden ofte stod tom eller brugtes som kvarter og lazaret. Under disse omstændigheder har da vel degnen som den tro, danske og pligtopfyldende mand, han var, reddet og passet embedets bøger, og inden han har afleveret disse til pastor Bang skrevet beretningen. En anden mulighed er, at det $i$ de umiddelbart følgende år er sket $i$ forståelse med pastor Bang eller dennes efterfølger Müller, der i 1867 måtte vige embedet, da han nægtede at aflægge troskabseden til den prøjsiske konge. 